\section{World Bank Receives National Wildlife Federation Award}

The World Bank has received the National Wildlife Federation's 1981 Special Conservation Award for its leadership in promoting environmentally-sound economic development. The award was made at the Fortysixth Annual Meeting of the Federation, held earlier this year in Milwaukee, Wisconsin.

The National Wildlife Federation, with 4.5 million members in the US and throughout the world, was founded in 1936, and now ranks among the largest of the world's non-profit, nongovernmental organizations dedicated to the environment.

In making the award, the Federation cited the World Bank for its well-established record of incorporating appropriate measures for protecting the environment in the projects which it finances. The citation said: 'Perhaps better than any other institution, the World Bank represents the idea that economic and environmental goals do not have to conflict. The World Bank pursues its business goals and at the same time insists on vigorous attention to resource management and the environment. Indeed, the Bank maintains that development is not worth while unless it is based on solid environmental planning and a global perspective.'

The World Bank's Environmental Adviser, Dr James A. Lee, accepted the award on behalf of the Bank's President, A.W. Clausen.

\section{Environmental Nature Note: African Rock Python and Thomson's Gazelle}

The African Rock Python, Python sebae, is one of the most widely distributed pythons in tropical Africa, being found from just south of the Sahara southwards to the Transvaal (Sprent, 1970). It occurs throughout Uganda and is particularly abundant on the islands of Lake Victoria (Pitman, 1938).
Pythons feed on frogs, toads, mice, rats, and other mammals, being able to take prey larger in size than their own bodies. They neither chew nor tear their food but swallow it whole. The African Rock Python, which reaches a maximum length of only $173 / 4 \mathrm{ft}(5.4 \mathrm{~m})$, has been known to swallow a fully-grown, horned Thomson's Gazelle (Gazella thomsoni), such as can run at more than 60 k.p.h. Post-mortem it was found that the victim's spine was fractured in four places. The pelvis and one thigh were also broken, and the prey was so distorted that the ribs on one side protruded through the other side of the body. The swallowing process can take as long as 90 minutes. When a freshly-killed pig weighing $40 \mathrm{~kg}$ was presented to another species of python measuring $20 \mathrm{ft}$ $(6.1 \mathrm{~m})$ in length, it was swallowed whole.

The method employed to kill large prey is to ensnare and suffocate it by coiling around and tightly squeezing the victim until it dies (Fig. 1).

Pythons and many other snakes have a series of modifications which enable the mouth to be widely distended to accommodate prey larger than themselves. These modifications are basically three but may be enumerated as follows:

1) Anteriorly, there is an elastic ligament joining the two mandibles (jaws).

2) There is loose attachment of the bone joining the skull and the jaw (the quadrate).

3) Bones of the roof of the mouth move (the palate bones).

4) The teeth are slender and point backwards, to prevent the food from slipping forward when once swallowing has begun.

5) Lack of a breastbone, so that the ribs are free ventrally and the thorax can be dilated.

6) Between the scales on the back and sides of the body there is soft, elastic skin which permits wide distension.

7) The gullet (oesophagus) and stomach have thin and easily-stretched walls.

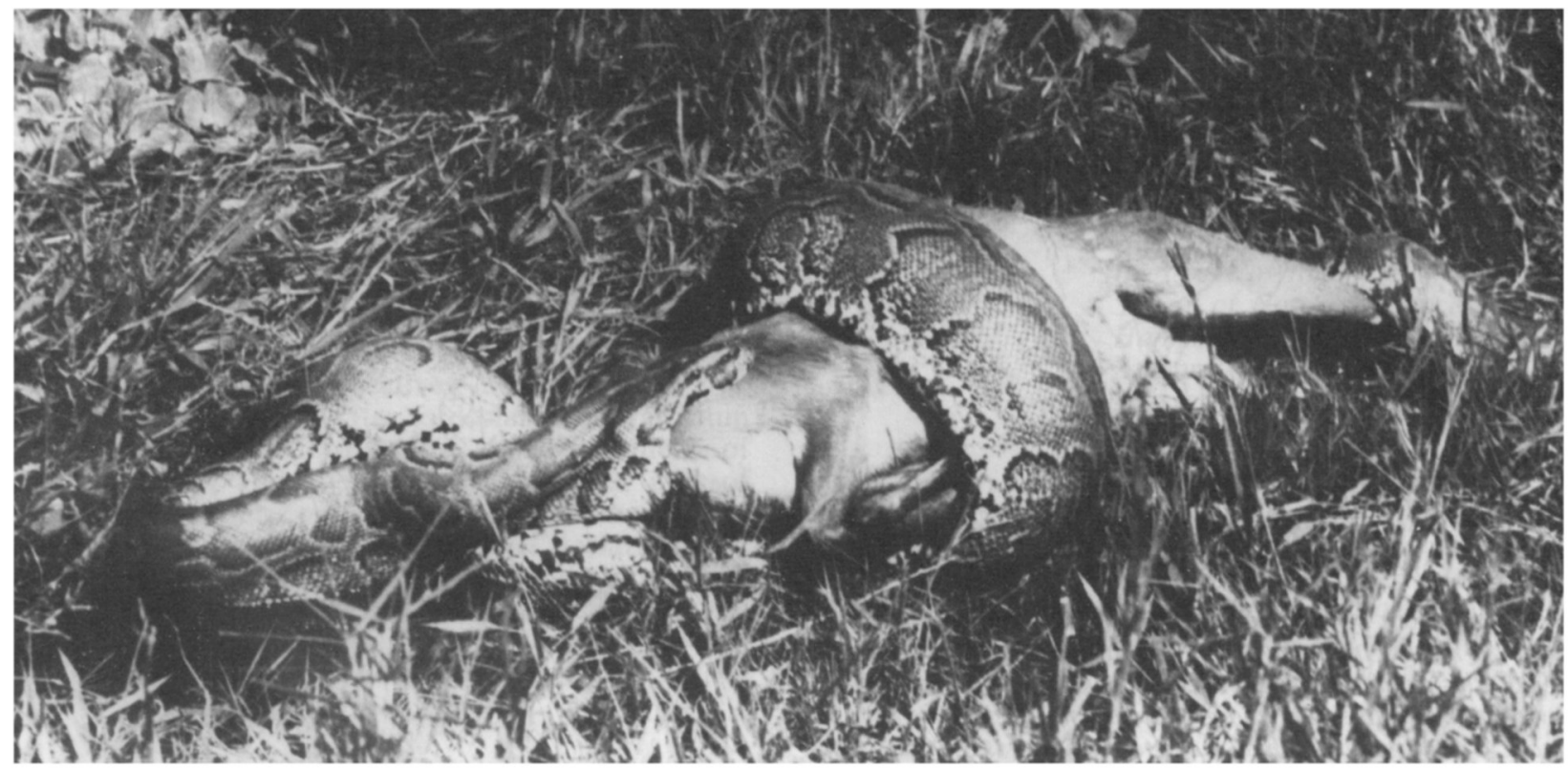

Fig. 1. Python swallowing a fully-grown, horned Thomson's Gazelle in a Uganda National Park. 
8) The Adam's apple (glottis) is far forward, between the jaws and just behind the sheath for the slender tongue, which permits breathing during the swallowing exercise.

\section{REFERENCES}

Pitman, C.S. R. (1938). A Guide to the Snakes of Uganda. Uganda Society, Kampala, Uganda, pp. 52-61.

SPRENT, J.F.A. (1970). Studies on ascaridoid nematodes in pythons. H.D. Srivastava Commemorative Volume, pp. 417-28.
E. RICHARD KIBERU
Department of Botany

\&

B. Makanga

Department of Zoology

Makerere University

P.O. Box 7062

Kampala, Uganda.

\section{Center Established for Data on Collapsed Structures}

What is believed to be the world's first repository for data on collapsed or damaged structures is being established at the University of Maryland, College Park, Maryland, USA, with the help of a \$73,839 grant from the National Science Foundation. By 1984, architects and engineers and others will be able to find information on collapsed or damaged buildings, bridges, roads, and dams, at the new facility, which is named the Architecture and Engineering Performance Information Center (AEPIC).

A joint project of the College of Engineering and the School of Architecture of the University of Maryland, the Center will be co-directed by Dr Donald W. Vannoy, Associate Professor of Civil Engineering, and Professor John Loss, Associate Dean of the School of Architecture. Previous attempts to document and analyse structural deficiencies have been tied to isolated incidents or handicapped by poor record-keeping. The chief advantage of the new Center is that soon, architects, engineers, and others, will be able to benefit from a comprehensive collection of data on many types of failures - such as the collapse of the Teton Dam in June 1976, or the collapse of Kansas City's Memorial Arena three years later.

'All structural failures-from something as catastrophic as the collapse of the balconies in the Kansas City Hyatt Regency to something as relatively minor as the premature wear-and-tear of a rural bridge-have at least one very important point in common, from which valuable information can be gathered, analysed, and reported', Dr Vannoy said. 'Our objective at AEPIC is to learn from these common points, so that we can improve structural design and prevent future disasters.'

Professor Loss added that: "Too often, it is only the dramatic cases of total building collapse which receive attention. One of the primary goals of the AEPIC Center will be to investigate also secondary design-flaws-flaws found in exterior walls, for example, and in roof-decks. This is critical, as these are the flaws responsible for a majority of building failures.'

More than 2,000 examples of reported building failures are already stored in the Center's data bases, and many more thousands of citations should be available to research workers and government agencies by 1984 .

In addition to establishing its own data-bank and reference library, the Center will serve as a prototype for repositories in universities and institutions world-wide. Dr Vannoy and Professor Loss already have corresponded with interested representatives from more than 14 American, British, Canadian, Swiss, and Italian, professional organizations.

RALPH KaZARIAN
National Science Foundation
1800 G Street
Washington
DC 20550, USA.

Facing the Axe in Ghana

A model forestry project at the Subri River Forest Reserve in western Ghana may soon fall victim to international pressure on Ghana to reform its currency. After six years' intensive research, and investment of nearly $\$ 4$ millions in the project, the UN Development Programme (UNDP) is withdrawing financial support. It has not explained why, but many aid donors are joining the International Monetary Fund (IMF) in exerting pressure on Ghana to devalue its currency. The World Bank, the European Community, or the Canadian government, might take over the project, but all have made devaluation a precondition.

The Subri experience could benefit tropical foresters everywhere, for no efficient method exists of establishing new plantations in tropical forests that have been ruined by years of cutting without replanting. The technique developed at Subri makes productive use of those trees which the axe leaves behind, instead of simply burning them. 'Burning off' is quick and easy, but the fire leaves an ideal seed-bed for weeds, and the cost of regular weedings often makes tree-planting uneconomical except for the highest-valued species.

At Subri, any young trees which might profitably be left to mature are identified and spared. Narrow belts of untouched natural forest are also preserved, to help maintain the ecological balance. The best of the lowvalue, left-over trees are cut, sawn, and sold locally, and the remainder are converted to charcoal. Burning is minimized to avoid weed infestation. Food crops-usually Plantain, Musa paradisiaca - are planted immediately on the cleared land, to maintain the ground-cover and help to keep down weeds. The food crop provides a useful additional source of income for the first few years. Finally, trees are planted between the rows of Plantain during the rainy season.

The cost of the Subri conversion technique is almost three times that of the conventional burn-and-weed approach, and it requires $37 \%$ more labour; but revenues from the sawn lumber, charcoal, and Plantain, make plantation establishment a net money-earner. However, the Government is caught between the need to maintain popular support and the requirements of the IMF and, so far, has refused to budge.

GEOFFREY BARNARD

Earthscan

10 Percy Street

London WIP ODR

England, UK. 